\title{
Indigenizing Student-Centred Learning: A Western Approach In An Indigenous Educational Institution
}

\author{
Chona Pineda Kennedy, Te Wānanga o Aotearoa, New Zealand and Curtin University, Australia
}

\begin{abstract}
This study investigated the alignment of the teaching and learning practices with a student-centred learning approach in an indigenous educational institution. The findings indicated that when a western concept is applied in the classroom, it is vital for it to be culturally relevant and appropriate to the cultural beliefs and values of the students and the institution. In an indigenous learning environment, learning and teaching that acknowledges the learner's cultural identity is seen as fundamental to their educational success and empowerment. The existent cultural elements of beliefs, values, language, heritage, heredity, perspectives and practices are clearly reinforced. The pedagogical approaches based on an indigenous framework must contextualise the learning experience, building upon students' background and aspirations. As an indigenous Māori organisation, Te Wānanga o Aotearoa (TWoA) offers a holistic learning environment and teaching methods where its philosophy, culture and values of Māoritanga (Māori culture and practices) and Mātauranga Māori (Māori knowledge) are strongly espoused.
\end{abstract}

Keywords: Student-Centred Learning; Indigenous Educational Institutions

\section{INTRODUCTION}

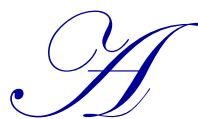

review of literature on adult education and student-centred learning reveals that current research does not address indigenous adult learners. In this study, the various dimensions of student-centred learning in the proposed integrative framework were derived from theories and practice of a number of mainstream researchers imbued with Western and/or Eurocentric concepts and pedagogies. Although the dimensions of student-centred learning are supported by sound research evidence, the framework and its dimensions may not be fully compatible or holistic when applied to a culturally indigenous learning institution. According to Nguyen, et al (2009) "simplistic forms of 'transfer' of western approaches to other contexts may often be inappropriate" (p.109). There is a need to ensure that the dimensions of the framework do not conflict with any of the cultural beliefs and values of the students and must be culturally appropriate. The dimensions need to be congruent and inclusive of the cultural identity, practices and pedagogical approaches of the institution and the learners. This is aligned with the APA Learner-Centred Psychological Principles where it stated under the Individual Differences domain that the differences in learners' linguistic, cultural, and social backgrounds must be taken into account in order for learning to be effective (Presidential Task Force on Psychology in Education, 1993). Adding the cultural factor will help provide a multi- faceted understanding of the phenomena of student-centred learning in all its complexity and richness.

It has been acknowledged that there is a link between adult learning and culture and that "culture pervades learning" (McLoughlin \& Oliver, 2000, p.59), therefore "a wide range of cultural influences will affect adult learning" (Sparks \& Butterwick, 2004, p.279). For some indigenous cultures, learning and teaching that acknowledges the learner's cultural identity is seen as vital to their educational success and empowerment. "Culturally relevant adult education can help learners validate their cultural identity and use their cultural knowledge as a basis for personal and social transformation" (Guy, 1999, p.5). Understanding of identity ("knowledge of who we are and what groups we belong to") (Sheets, 2005, p.50) is crucial both on the part of the learners as well as the 
tutors for the successful achievement of the students. Likewise, "learning is also seen as a central way of combating cultural domination and oppression" (Guy, 1999, p.12). Mc Loughlin and Oliver highlighted (2000, p.62) that "instructional design models include cognitive, social and pedagogical issues, but may not acknowledge the need for cultural conceptuality". These views highlight that the learning process of students and how they learn should not be divorced from their cultural upbringing and identity. It is therefore important that the other perspectives and worldviews, apart from the dominant Western discourses about adult learning, is accorded value and due consideration. "When such adaptation is not forthcoming, the results may be cultural mismatch and ineffective outcomes" (Phuong-Mai, Terlouw, Pilot, \& Elliott, 2009, p.2). Learning and teaching practices that respect and acknowledge the differences in culture allow learners to "maintain the integrity of their cultural identity as they succeed in their educational goal" (Salili \& Hoosain, 2007, p.4). Acknowledging the cultural identity in the learning and teaching strategies allows the students to be comfortable in their learning environment.

Bourdieu's (1977; Bourdieu \& Passeron, 1990) concept on cultural capital (which comes in various distinct types) argues that similar with economic capital, individuals and families have accumulated resources, wealth and knowledge which position them at a much higher level than others. Similarly, Di Maggio (1982) who also explored cultural capital argued that the different aspects of culture also have impact on cognition and educational achievement. The authors linked cultural capital with educational success. This seemingly important role and consequence that culture plays in education is not reflected in current discourses which "from an intercultural perspective, do not include a systematic focus on both the theoretical implications and empirical evidence of cultural diversity as a central feature of higher education" (Editorial, 2009, para. 2). McLoughlin and Oliver (2000) indicated that one of the limitations in the classroom instructional models, "is that they do not fully contextualise the learning experience, and are themselves the product of particular cultures (p.58)". Tutors' approaches must be able to facilitate learning that builds upon and relates to students' background, interest and relevance in their learning goals. In line with this, McAnany (2009) recommended principles based from the discourses in multiculturalism: in order to educate and broaden the worldviews of the learners, instructional design must incorporate global concepts and images, must not be offensive and that they must know the learner in order to design their instruction for each specific culture. A grounded understanding of the impact of culture on the design of the learning environment must take into consideration the context, historical as well as current conditions of the students. However, Zhao (2007) highlighted the following pitfall in accommodating students' cultural differences:

We may fall into the trap or reifying superficially or even ethnocentrically understood cultural differences and pigeonholing students simply because of their assumed 'cultural differences'. Applying our simplistic understanding of other cultures could constrain our students ( p. 473-474).

Educators therefore need to ensure that being culturally aware and sensitive is not a lip service, but must be demonstrated by making genuine connection and providing dynamic and flexible pedagogical strategies to accommodate the cultural diversity in the classroom.

Culture, although complex can also be understood in broad universal terms, regardless of the field of discipline, as "the repository of values, customs, and achievements, which one generation leaves as a 'testament' to its descendants" (Palaiologou, 2009, p.189). This includes a collective "sharing of knowledge, beliefs, values and meaning, as well as norms and behaviour" (Salili \& Hoosain, 2007, p.4). There are salient dimensions or items of cultural differences which affect the learning approaches or preferences and outcomes of students. It is expected that educators develop a sense of cultural awareness and sensitivity by allowing flexibility and diversity to provide greater opportunities for learners to succeed. Joy and Kolb's (2009) research on the impact that culture plays in the learning styles of students from various cultures confirmed that culture indeed "significantly influences learning style, particularly the extent to which individuals rely on concrete experiences versus abstract concepts in the way they learn" (p. 84). Sheets (2005) highlighted that the desire to have positive outcome for students of different cultures will "depend on the teacher's ability to conceptualize the role of culture and apply it in the teachinglearning process" (p. 12). This view highlights the need for teaching approaches to be responsive to the cultural diversity in the classroom.

Culture has an impact on the way learners go about their learning, which may lead to having different learning orientation and processes for students of different cultures. In the Asian perspective where the cultural 
context in education is influenced by Confucianism, Western pedagogies can be quite incongruent with the Asian ways of knowing and learning and teaching. Promoting competition in the classroom and other approaches to teaching where students are rewarded to motivate them to learn is not effective for many minority students across many cultures. In South Africa, educators are expected to be promoting cultural sensitivity by acknowledging the rich, diverse values that characterise the worldview and way of life of the different people within their country who are still very much connected to their ethnic attributes and or linguistic heritages (Modiba \& van Rensburg, 2009). Students are encouraged to express their identities through cultural symbols and practice as well as being open to the presence of cultural hybridity in the classroom. A more holistic approach in the learning and teaching is preferred by many minority cultures.

In an indigenous learning institution, the existent cultural elements of beliefs, values, language, heritage, heredity, perspectives and practices are clearly reinforced. For example, the American Indian/ Alaska Native students have deeply rooted learning and teaching process where their distinctive cultural values and strong tribal social hierarchy are deeply engrained (Pewewardy, 2002). The African indigenous knowledge systems, as Breidlied (2009, p. 141) posited, "must be understood in relation to a worldview which is to a large extent realised in religious ceremonies, ritual and other practices". Likewise, Guy (1999) argued for the development of "culturally relevant education" (p. 6) and "approaches to learning and teaching based on the sociocultural experiences and backgrounds of the population" (p. 6) as a way of helping the marginalised. In a longitudinal study of indigenous Australian University students conducted by Boulton-Lewis, Wills and Lewis (2003) found a dissonance between the students' conceptions and strategies of learning. The authors postulated that this could be explained as being due to "lack of fit between the university learning context and how these students prefer to learn, and this may be due to cultural influences on learning that are specific to Indigenous students" (Boulton-Lewis, et al., 2003, p. 86). To accommodate individual learners, tools, strategies and methods of instructions must be flexible and adapted to the unique learning processes of individual learners (Guild, 2001). Indeed "culturally appropriate pedagogy" (Zhao, 2007 , p. 473) has become necessary not only to mono cultural class of students but as well as in acknowledging the very diverse class of the student population which requires sensitivity from the part of the tutors to acknowledge and accommodate their cultural differences. While "the question of culture and style are not easy to address, they are crucial to contemplate together"(Guild, 2001). It is important that teaching and learning approaches are culturally relevant and provide due consideration to the diversity in a multi-cultural classroom (McAnany, 2009).

\section{MĀORI PEDAGOGIES}

The Māori people are the indigenous people of New Zealand, the tangata whenua (people of the land). They therefore have their own deeply ingrained Māori values, principles and tradition which are practiced in the teaching and learning context. According to Bishop (2003) "current educational policies and practices, in Aotearoa/New Zealand, as in most western countries, were developed and continue to be developed within a pattern of power imbalances which favours cultural deficit explanations" (Bishop, 2003, p. 221). For the Māori people, the imposition of the dominant Western theories and worldviews which are inconsistent with the Māori epistemologies and pedagogy are found to be ineffective in akoranga Māori (Māori learning). Bishop (2003) and Smith (1999) promote the reaffirmation and empowerment of indigenous Māori cultural aspirations through the Kaupapa Māori theory and practice which are proven to be beneficial for Māori as a way of addressing the imbalances in the classroom. "In Kaupapa Māori contexts, the interrelationships and interaction patterns draw on Māori cultural aspirations and sense-making processes (ways of knowing) rather than on those imposed by another culture" (Bishop, 2003, p. 223). Mātauranga Māori (Māori pedagogy), also based from traditional Māori concepts and built upon Kaupapa Māori principles, presents teaching and learning approaches which are considered to be effective in engaging Māori learners. A pedagogical practice that acknowledges and respects the distinction of the indigenous customs and traditions is crucial to the success of the learners.

Edwards \& Hewitson (p. 98) discussed "creating tertiary educational programmes based on Indigenous epistemologies and worldviews as well as adopting systems that normalise Māori epistemologies" as a way of countering hegemony through education. This is the "culturally preferred pedagogy" for Māori which promotes principles for "teaching and learning practices that are unique to Tikanga Māori”(Pihama, Smith, Tahi, \& Lee, 2004, p. 47). Rather than being disconnected from Māori philosophy, practice and context, the learning and teaching approaches are designed to be culturally appropriate to empower Māori identity. Embedding Māori ways of 
knowing and following Tikanga Māori and Mātauranga Māori principles and philosophies in teaching and learning practices are a way of addressing the disparity in the educational achievement of Māori.

A number of fundamental metaphors with specific meanings for Māori have been identified in the educational settings which allowed them to "develop markedly different modes of theorising and means of addressing educational relationships for and with Māori students in the mainstream settings..." (Bishop, 2003, p. 225). For example, the concept of Ako, a traditional Māori concept for both teaching and learning, derived from a Māori cultural framework is considered to be the preferred way of learning and teaching for Māori students (Lee, 2004). This concept promotes reciprocal learning where power is shared in the classroom. Students and tutors learn from each other; and make meaningful contribution and participation. At Te Wānanga o Aotearoa, development is in progress regarding Ako Wānanga, a teaching and learning approach that "seeks to design, develop and implement a TWoA andragogy... [taking] the appropriate elements of Māori worldview and to apply them in the challenging contemporary time" (Edwards, 2011, p. 1). Ako Wānanga is based on a Mātauranga Māori framework that include teaching and learning approaches that enhances the holistic well-being of Māori learners. Edwards (2011, p. 3) described Ako Wānanga futher stating that:

Ako Wānanga is the educational philosophy and practice of teaching and learning, the Te Wānanga o Aotearoa way, inspired and informed by three pou (pillar) of our organization:

- $\quad$ Te Kaupapa o Te Wānanga O Aotearoa;

- $\quad$ Nga Uara (values); and

- $\quad$ Nga takepu (principles) of Kaupapa Wānanga.

A holistic approach to learning is also valued and perceived to work well in culturally diverse students. "Historically, Māori engagement in learning was holistic - meaning that learning occurred in all situations and context" (Mlcek et al., 2009, p. 9). The focus was not limited to academic development for the students but also other factors in their well-being such as social, cultural and spiritual well-being. Durie (1994) for example developed the metaphor 'Te Whare Tapa Wha' (the strong house) where the house represents the learner in the teaching and learning context. Durie claimed that a balanced well-being is underpinned by four dimensions. These are te taha hinengaro (psychological health); te taha wairua (spiritual health); te taha tinana (physical health); and te taha whānau (family health). These dimensions serve as principles for Māori pedagogy where the teaching and learning approaches are built upon. In addition, the metaphor Whanau (extended family) in the field of education reinforces the need to have whanau-type relationship and a collective sharing of values and collaborative sharing of responsibilities in the teaching and learning (Bishop, 2003).

Likewise, Māori cultural identities are reinforced through the embedding of Tikanga Māori values and traditions in the pedagogical practices. These are exemplified in the classroom through active engagement and participation in a number of Māori traditional, cultural activities. (e.g. starting the day with a karakia (thanks giving and blessings), using whakatauki (proverbs), mihi (greetings and acknowledgment), singing waiata ( songs) or participation in pōwhiri (welcome ceremony) and kapa haka (performance art). The use of whakapapa (genealogy) was "referred to the layering of knowledge, which alludes to a belief that knowledge must be acquired gradually" (Mlcek, et al., 2009, p. 10). This is similar to the scaffolding strategy. Citing other authors, Mlcek et al. also referred to "Karakia being used before, during and after learning to ensure receptivity to and retention of knowledge"...(Mlcek, et al., 2009, p. 10). “...Whakawhanaungatanga (the process of building relationships) [is another] key tikanga (culturally responsive approach) for improving behavior and learning outcomes for Māori students" (Macfarlane, Glynn, Cavanagh, \& Bateman, 2007). At TWoA, delivery of programmes through noho (live-in) or wānanga as delivery methods in a marae (Māori traditional meeting house) as a place of learning are considered to be important for Māori. George (2012, p.436) defined Marae as "places of refuge, places of learning; spaces of rest and respite where the active expression of Māori culture is most obvious". The teaching and learning practices at TWoA which are firmly rooted in āhuatanga Māori are found to be vital and intrinsic in akoranga Māori (Māori learning). They are considered to be pedagogical approaches that will address the disparity in Māori student achievement in comparison with the non-Māori. 


\section{CONCLUSION}

Adding and recognizing the cultural capital of the students recognises the fact that the participants and the institution where this research took place have a very high regard of their cultural identity. With this, it can be stated that the pedagogical approaches include all aspects of teaching and learning with the student as the centre of all the activities. Being culturally responsive in the teaching and learning strategies is critical in the enhancement of the quality of learning in a multi-cultural classroom. However, the success of its implementation is dependent on context, as well as the role played by the organisation, tutor and students themselves. In this study, indigenous education, in particular Mātauranga Māori was considered to be of prime importance in the quality of the delivery of education for Māori students. Utilising indigenous pedagogical practices validate Māori aspirations and strengthen their cultural identity.

\section{AUTHOR INFORMATION}

Chona Pineda Kennedy is the Manager of Student Registry Unit at Te Wānanga o Aotearoa in New Zealand. She is currently enrolled at Curtin University in Perth, Western Australia for her $\mathrm{PhD}$ in Education. Chona has undergraduate degrees in Bachelor of Arts major in Economics and Bachelor of Adult Education. She also has her Master in Business Administration (MBA). E-mail: Chona.Kennedy@twoa.ac.nz

\section{REFERENCES}

1. Bishop, R. (2003). Changing power relations in education: Kaupapa Maori messages for 'mainstream' education in Aotearoa/New Zealand. Comparative Education, 39(2), 221-238.

2. Boulton-Lewis, G., Wills, L., \& Lewis, D. (2003). Dissonance between Conceptions of Learning and Ways of Learning for Indigenous Australian University Students. Studies in Higher Education, 28(1), 79-89.

3. Bourdieu, P. (1977). Reproduction in Education, Society, Culture. Beverly Hills, CA: Sage.

4. Bourdieu, P., \& Passeron, J. (1990). Reproduction in Education, Society and Culture. London: Sage.

5. Breidlid, A. (2009). Culture, indigenous knowledge systems and sustainable development: A critical view of education in an African context. International Journal of Educational Development, 29, 140-148.

6. DiMaggio, P. (1982). Cultural capital and school success: The impact of status culture participation on the grade of U.S. high school students. American Sociological Review(47), 189-201.

7. Durie, M. (1994). Whaiora: Maori health development. Auckland, New Zealand: Oxford University Press.

8. Editorial. (2009). Interculturality and higher education. Intercultural Education, 20(5).

9. Edwards, S. (2011). Ako Wānanga: The Art, Science and Spiritual Endeavour of Teaching and Learning in a Wānanga: A Localised Approach. Te Wananga o Aotearoa. Te Awamutu.

10. Edwards, S., \& Hewitson, K. (2008). Indigenous epistemologies in tertiary education. The Australian Journal of Indigenous Education, 37, 96-102.

11. George, L. (2012). Expressions of Maori multiplicity in (re)connection to nga taonga tuku iho. Social Identities, 18(4), 435-450.

12. Guild, P. (2001). Diversity, learning style and culture. Retrieved from http://www.newhorizons.org/strategies/styles/guild.htm

13. Guy, T. (1999). Culture as context for adult education: The need for culturally relevant adult education. New Directions for Adult and Continuin Education(82), 5-18.

14. Joy, S., \& Kolb, D. (2009). Are there cultural differences in learning style? International Journal of Intercultural Relations, 33, 69-85. doi: 10.1016/j.ijintrel.2008.11.002

15. Lee, J. (2004). Articulating Ako: Maori pedagogy in New Zealand Education. International Journal of Diversity in Organisations, Communities and Nations, 4, 563-571.

16. Macfarlane, A., Glynn, T., Cavanagh, T., \& Bateman, S. (2007). Creating culturally-safe schools for Maori students. The Australian Journal of Indigenous Education, 36, 65-100.

17. McAnany, D. (2009). Monkeys on the screen?: Multicultural Issues in Instructional Message Design. Canadian Journal of Learning and Technology, 35(1).

18. McLoughlin, C., \& Oliver, R. (2000). Designing learning environments for cultural inclusivity: A case study of indigenous online learning at tertiary level. Australian Journal of Educational Technology, 16(1), 58-72. 
19. Mlcek, S., Timutimu, N., Mika, C., Aranga, M., Taipeti, N., Rangihau, T., ... McGarvey, H. (2009). Te piko o te mahuri, tera te tupu o te rakau: Language and literacy in marae-based programmes. Wellington, New Zealand: Ministry of Education.

20. Modiba, M., \& van Rensburg, W. (2009). Cultural diversity in the classroom: implications for curriculum literacy in South African classrooms. Pedagogy, Culture and Society, 17(2), 177-187.

21. Nguyen, P., Elliott, J., Terlouw, C., \& Pilot, A. (2009). Neocolonialism in education: Cooperative Learning in an Asian context. Comparative Education, 45(1), 109-130. doi: 10.1080/03050060802661428

22. Palaiologou, N. (2009). Needs for developing culturally oriented supportive learning with the aid of Information and Communication Technologies. Pedagogy, Culture and Society, 17(20), 189-200. doi: $10.1080 / 14681360902934434$

23. Pewewardy, C. (2002). Learning styles of American Indian/Alaska Native students: A review of literature and implications for practice. Journal of American Indian Education, 41(3), 22-56.

24. Phuong-Mai, N., Terlouw, C., Pilot, A., \& Elliott, J. (2009). Cooperative learning that features a culturally appropriate pedagogy. British Educational Research Journal, 2009, 1-19. doi: 10.1080/01412920802688762

25. Pihama, L., Smith, K., Tahi, M., \& Lee, J. (2004). A Literature Review on Kaupapa Maori and Maori Education Pedagogy. Wellington: The International Research Institute for Maori and Indigenous Education.

26. Salili, F., \& Hoosain, R. (Eds.). (2007). Culture, Motivation, and Learning. Charlotte, NC: Information Age Publishing Inc.

27. Sheets, R. (2005). Diversity pedagogy: Examing the role of culture in the teaching-learning process. Boston, MA: Pearson Education Inc.

28. Smith, L. (1999). Decolonising methodologies: Research and Indigenous people. London/Dunedin: Zed Books/University of Otago Press.

29. Sparks, B., \& Butterwick, S. (2004). Culture, equity and learning. In G. Foley (Ed.), Dimensions of adult learning: Adult education and training in a global era. NSW, Australia: Allen \& Unwin.

30. Zhao, G. (2007). Culturally appropriate pedagogy: Is it always necessary? The case of East Asians learning math and science. Intercultural Education, 18(5), 473-486. doi: 10.1080/14675980701685339 